\title{
Water as Resource and Being: Water Extractivism and Life Projects in Peru
}

\author{
Astrid B. Stensrud
}

\section{INTRODUCTION}

'In Majes we are at war against a hostile and tough topography, against a nature that we must change, we are at war with the underdevelopment and this makes us impatient.' These were the words of engineer Oscar Valdivia Ávalos, the CEO of the Majes Irrigation Project (MIP), ${ }^{1}$ in the speech he held after signing a contract for completing the project in 1977 (Zamalloa 2013: 36). MIP consists of the Condoroma dam at 4158 metres of altitude in the headwaters of the Colca-Majes watershed in the southern Peruvian Andes, in addition to the Majes Canal, a planned hydropower plant, and an extensive network of irrigation infrastructure that will cover more than 50,000 hectares in the desert flatlands of Majes. As of 2017, 15,800 hectares have been irrigated, while the upcoming second phase-in which the remaining 38,500 hectares will be irrigated-has been delayed due to various reasons like shifting governments, economic crisis, and, after 2010 , protests against the new dam in the highlands. MIP is part of the Peruvian government's vision of development: to master nature in order to exploit it and to use water and land
A. B. Stensrud $(\bowtie)$
University of Oslo, Oslo, Norway
e-mail: a.b.stensrud@sai.uio.no

(C) The Author(s) 2019

C. Vindal Ødegaard, J. J. Rivera Andía (eds.), Indigenous Life

Projects and Extractivism, Approaches to Social Inequality and

Difference, https://doi.org/10.1007/978-3-319-93435-8_6 
to create as much economic value as possible. This is what I call water extractivism in this chapter: the practice to singularise and standardise water into the category of 'resource' in order to master it and extract as much economic value from it as possible. The war of the Peruvian state was - and still is - not only against topography and nature, it is also a war against the other-than-human beings who inhabit the steep mountain landscape that seem hostile to engineers and politicians, yet is home to thousands of peasant farmers and their alpacas and other animals. The mountains can be hostile, indeed; by local indigenous farmers, they are known to be sentient, capricious, and unpredictable and to 'eat' those who disrespect them. This world of living earth-beings is what the CEO called 'underdevelopment' and a 'nature that we must change'. The dominant view held by most of the political and economic elite based mainly in Lima has, since the start of the Peruvian Republic, been that the world- and life-making projects of the Quechua-speaking peasant farmers in the highlands are 'backward' and hinder modernity and development. Indigenous life projects are excluded from the design of megaprojects of modernity, and they are considered to be irrelevant and dispensable in the war against underdevelopment and in the pursuit of progress.

People in poor rural areas in the Andes tend to welcome megaprojects because they hope for employment and benefits such as improvements of roads, construction of schools, and other material gains, yet they often perceive development projects to be intrusive and as causing trouble. It is important to note, however, that hydraulic infrastructure is not unknown to farmers in Colca Valley, where farmers use a complex network of canals and pipes to bring water from the mountain springs to their ponds and cultivated fields. What makes MIP different is the large scale of the canal and the unequal distribution of benefits and power. During the planning and construction of MIP, the possible consequences for the farmers and their life-worlds in Colca Valley were not taken into consideration. Yet, the impact was huge; MIP transformed the ecological and social composition of the watershed and opened spaces for economic and political demands and struggles. Those who have gained access to water from the Majes Canal have accepted paying a higher irrigation tariff for the water from the Majes Canal than they pay for water coming from natural springs, and in return, many have extended their areas of cultivation.

Almost 40 years after the speech referred to above, the Peruvian state is still at war against an unruly 'nature' and practices that are seen as standing in the way of economic growth and 'progress'. Especially since the 1990s, 
development policies in Peru have been based on a neoliberal model of deregulation, private investment, and extractivism and extensive concessions have been granted to foreign corporations that extract value from nature. The extractive practices that have created most socio-environmental conflicts and have received most attention have been related to the boom in oil, minerals, and logging. Another form of extractivism that is growing in importance in Peru is the extraction of economic value from water in infrastructural megaprojects that are damming and channelling water from the highlands to the arid coast in order to enable large-scale exportoriented corporate agribusiness. One example of these megaprojects is the MIP, which is now going into its second phase, Majes-Siguas II, and which is generating tensions and conflicts.

The expansion of MIP is provoking reactions, for example, from people in the headwater district Callalli where the Condoroma Dam is located and where people have not received any benefits from the dam. The people in Callalli make claims to land areas in Majes based on their asserted ownership to the water that originates in their territory and that enables economic growth in Majes. In this chapter, I explore the conditions that make this land claim possible and discuss how it is connected to notions of belonging and ownership that emerge from particular ontological relations of water, mountains, earth, and human and nonhuman beings. These relations are made through world- and life-making practices and projects, which, although they are often entangled, tend to diverge radically from the projects of modernisation, progress, and economic growth based on extractivism.

Mario Blaser (2004) has argued that indigenous communities do not just resist development and do not just react to state and market; they also sustain 'life projects' that are embedded in local histories and visions of the world and the future that are distinct from those embodied by projects promoted by state and markets. These life projects 'are premised on densely and uniquely woven "threads" of landscapes, memories, expectations and desires' (Blaser 2004: 26). The weaving practices that make the 'threads' in Colca-Majes are what I call world-making practices, or ontological practices, from which humans and other-than-humans (earthmothers, water-mothers, mountain-beings, and other entities) emerge. These practices enact the possibility of fertility, goodwill, and protection as well as the prevention of accidents: the safeguarding of water supply, ensuring the potato harvest, and making sure that the irrigation canals and ponds will endure and work well (see also Stensrud 2016). I see 'reality' as not preceding the mundane practices in which we interact with it but 
rather as being shaped and enacted in these practices (Mol 2002). This analytical lens entails seeing emergence instead of relations between bounded 'units' of indigeneity and modernity (de la Cadena 2015a). A dynamic approach that focuses on life projects, world-making practices, and what emerges from them can contribute to a more nuanced understanding of reactions and interactions within a megaproject like MIP.

While life-making projects in the Andes are constituted by relational practices of reciprocity, extractivist projects come from a colonial practice of conquest. I argue that extractivist policies and practices that support megaprojects like MIP are radically different from life-making projects that consist of maintaining a livelihood of small-scale farming by interacting with water and other earth-beings. Extractivist and life-making projects can be intrinsically entangled in practice-for example, some farmers who work for MIP or in mines participate in both extractivist and lifemaking projects - and all uses of water imply different kinds of appropriation. Yet, I maintain that a logic based on extractivism and conquest is not compatible with the logic of relationality and reciprocity. Megaprojects are projects of modernity and hence coloniality, which is not only the heritage of colonialism but is constitutive of modernity (Mignolo 2000; Escobar 2007; Maldonado-Torres 2007). Coloniality is a discourse and practice that simultaneously preach the natural inferiority of subjects and the colonisation of nature, which mark certain subjects as dispensable and nature as pure raw material for the production of goods in the international market (Maldonado-Torres 2007: 135). Coloniality can be understood as the radicalisation and naturalisation of the non-ethics of war, representing a sort of exception to the ethics that regulate normal conduct, which justify slaving and eliminating dispensable subjects (Maldonado-Torres 2007: 138). The idea that certain people are dispensable can be seen as deriving from an unrecognised implication of Descartes' cogito ergo sum: 'I think (others do not think, or do not think properly), therefore I am (others are-not, lack being, should not exist or are dispensable)' (MaldonadoTorres 2007: 144). Hence, to not think 'rationally' according to a paradigm of efficiency and 'progress' is made into a sign of nonbeing in modern society where profitability and economic growth are more important than ways of maintaining life projects and worlds that are categorised as 'other'. The subjects that are rendered dispensable in Peru comprise not only indigenous subjects but also other-than-human beings, including earth- and water-beings. When water is appropriated to extract economic value, it is part of a practice that not only colonises water as resource but also water practices that diverge from the logic of extractivism. 


\section{Conquering Water}

In the 1970s, MIP was considered 'the world's most expensive irrigation project' (CIP 2013), and the total investment was USD 630 million, 35 per cent of which was financed by the state (Zamalloa 2013: 38). The rest was financed by international loans, and the infrastructure was built by the consortium MACON (Majes Consorcio), consisting of five private companies from Sweden, England, South Africa, Canada, and Spain. MACON built the Condoroma dam in Callalli District, the downriver water intake in Tuti District, and the Canal Majes: 88 kilometres of tunnels and 13 kilometres of open canal through the districts of Tuti, Chivay, Yanque, Achoma, Maca, Cabanaconde, and Huambo. The execution of the MIP was started during the left-wing regime of Velasco (1968-75), who endeavoured to bring Peru into an era of progress: the 1969 agrarian reform ended the dominant power of the large estate owners in the highlands (Collier 1978) and the same year water was nationalised by the General Water Law (Ley General de Aguas) (del Castillo 1994). Velasco's reforms were intended to help poor indigenous peasants but mainly focused on class and socio-economic issues and did not include indigenous designs and multiple life projects.

The construction phase, which the CEO called a 'war against nature', is remembered by many people in Colca Valley as a time of rapid change and intrusive encounters. In 1972, construction began on the water intake in Tuti and Majes Canal. MACON brought specialists from all over the world and workers from other parts of Peru, who were stationed in an encampment in Achoma District. In the years that they lived and worked there, the MACON workers, and especially the foreigners, were highly visible in Colca. 'That was the first time we saw gringos; there was no tourism yet', a man in his 50s commented. His name was Edwin and he told me that when he had been a young boy in the 1970s, the MACON gringos, also called 'los macones', used to drink in his father's cantina (tavern). 'Los macones have done whatever they wanted here', he commented. According to Paul Gelles, who did fieldwork in the community of Cabanaconde in the 1980s, most local people lamented the changes and abuses the project brought; stores were opened to meet the demands from a booming economy and 'everything became money'. The MACON workers abused the local people, and there were incidents of prostitution and rape (Gelles 2000: 61).

MACON offered temporary jobs to local men-low-paid manual labour in the construction of the dam, the water intake, the canal, and tunnels. This work was dangerous and many lives were lost in the tunnels and the construction sites. One of Edwin's relatives was killed in an accident in Tuti 
when his poncho got stuck in the machinery at night. In the eyes of local people, MACON challenged the respect for the powerful mountains as they used dynamite to make the Majes Canal and the tunnels, and it was, therefore, necessary to make offerings (pagos) to avoid accidents. Accidents are often talked about as being eaten by hungry mountains, or being lured by beings inside the mountains, called devils or chinchilikos. Old farmers who had worked as labourers in the making of tunnels remembered the chinchilikos: small underground creatures, also called dwarfs, devils, miners, or just 'small men with helmets', who appeared inside the mountains. ${ }^{2}$ By offering you gold and silver, they can drag you inside the mountain and make you disappear. The daughter of a man who had met a chinchiliko in the Majes tunnel told me that when the devil drags you (te jala), it is the same as when the mountain eats you. In southern Andean Peru, it is a common practice to pay offerings and ask earth-beings for permission to make roads, tunnels, and mines (cf. Harvey and Knox 2015). Although this was not (and could hardly be) part of the official work strategy of MACON, I was told that MACON workers also engaged in such practices. For example, Edwin told the story of a poor beggar who suddenly disappeared. A rumour was spread that the MACON workers had sacrificed him to the mountain to avoid accidents. According to the rumour, they had made him drunk and after he had passed out, they put him in the pago and buried him alive. I also heard that 'they put a human foetus in the pago' before starting the construction of the water intake in Tuti, but it was never made clear to me who 'they' were. It could very well be that both local people and MACON workers from other parts of highland Peru wished to reduce the risk of fatal accidents.

These stories are not testimonies that give precise details about the past but serve to explain how situations and relations are perceived and how connections are made. The stories have broad resonance in the ethnographic literature from the Andes, for example, in Nash's (1979) study of how mine workers in Bolivia relate to el Tio-also associated with the devil-who is the owner of the mountain and who they must give offerings to before taking out minerals (see also Fernández Juárez 2013). In Taussig's interpretation, offering to el Tío as the devil of the mine is a reaction to capitalist modes of production. In the precolonial Andes, there was no conception or reification of an evil spirit: 'evil was neither reified nor fetishized, neither a thing opposed to good nor a thing spiritualized like the devil' (Taussig 1980: 169). The fetishisation of evil in the form of the devil was created after the Spanish Conquest, along with the new forms of class oppression (Taussig 1980). The earth-beings had to assimilate to the Christian religion or descend underground to the world within/below called ukhu pacha in order to become 
invisible, and some of these beings were identified with the devil (Cereceda 2006). Rather than understanding the chinchiliko as a symbol of Christian or capitalist oppression, I see it as an entity that emerged in encounters between worlds of different nature-culture constellations: a relational world where all living beings are connected versus a 'modern' world where nature is seen as a resource to be exploited or as a container from which value can be extracted.

In the dominant discourse of modernisation and progress, indigenous practices are ridiculed and seen as 'ancient' customs that should be eradicated because they are hindering progress and economic growth. This view was publicly stated by President Alan García in an interview on national television in 2011:

[We] must defeat the absurd pantheistic ideologies that believe that walls are gods, that the air is god, the return to these primitive forms of religion, where they say do not touch that mountain because it is an apu and full of a millenarian spirit [...]. That we are advancing does not mean that all our ancient forms of thought have been overcome. (Los Andes 2011)

The encounters with sentient mountains and chinchilikos are not part of the official story of the Majes Project. As in other official histories of extractivist 'development' in the Andes, the earth-beings are denied real existence or are tolerated as indigenous belief or superstition (de la Cadena 2015a, b). Yet, in Colca, the stories are told again and again. The arrival of MACON in Colca Valley was, and still is, perceived as a powerful intrusion that disrespected local people as well as the living mountains. Lifemaking projects that interact with earth-beings are not remnants from an ancient past but are continuously sustained and re-invented in light of globalisation and changing environmental conditions.

\section{RESPECTING WATER}

The Tuti intake station directs water that would normally flow down the Colca River into the Majes Canal. Since the river runs in the deep Colca Canyon, the farmers have never used this water for irrigation. Today, farmers take water from valves in the large Majes Canal, which are connected by small canals to the old network of irrigation canals in the valley. Irrigation has always been important in the arid Colca Valley, but it becomes even more crucial with the shortened rain seasons that farmers have experienced in the past few years. Making irrigation systems work requires the maintenance of physical infrastructure as well as different kinds of relationships: 
cooperation within and between communities and the goodwill of the mountains and springs that supply the water. The work of the 33 irrigation associations of the valley, called water users' commissions (comisiones de usuarios), and of the Water Users' Board of Colca Valley (Junta de Usuarios Valle de Colca) is very important in this regard. The approximate ten thousand smallholding farmers in Colca Valley are organised in these associations. They are proud of their hydraulic infrastructures, which constitute a complex network of hundreds of kilometres of canals and pipes that connect the springs, lakes, glaciers, ponds, and small reservoirs with the pastures and fields. While the large-scale Majes Canal is maintained by AUTODEMA (Autoridad Autónoma de Majes), the state entity in charge of MIP, the small-scale infrastructure is built and maintained in collective work parties, where all water users are obligated to participate in order to have the right to use water. Every August, which is the month before the start of a new sowing season, each association organises the main cleaning of their irrigation infrastructure followed by festive celebrations.

The irrigation systems necessitate cooperation between communities. For example, the village called Yanque must bring water from the neighbouring districts. Each year, in August, they organise collective work to clean the long irrigation canals from the Huarancante mountain in Chivay and the Canal Mismi, which goes 25 kilometres from Mount Mismi in Tuti District, through Coporaque District and down to Yanque. The cleaning work takes four days for the group of farmers who go up to the source and descend by foot while they clean the canal with shovels. Before starting the work, it is important to make pago to the mountains so that no accidents or deaths will happen. Proper offerings also have to be made to the ponds and canals that are going to be cleaned and repaired. The night before cleaning the main pond in Coporaque, in 2011, the two water users' commissions each made a pago to the pond. They put the pagos in a box buried deep in the earth beside the gate, where they also keep small miniatures of llamas that are taken out to be 'read' and interpreted before they are returned. The wine goblet should be empty - this means that the earth-mother of this place and this pond is content-before it is filled with new wine. According to Catherine Allen, ritual practices in the Andes are 'premised on a principle of consubstantiality, the assumption that all beings are intrinsically interconnected through their sharing a matrix of animated substance' (Allen 1997: 75). Hydraulic infrastructure, such as ponds and canals, cannot be seen as separate from the entangled world of soil, water, earth-beings, and other animated entities in the surroundings. After the work is finished, all participants celebrate with food, drink, and dance. When the water, which has been withheld during the work, 
is released, it is received with reverence and joy. Farmers in Yanque and Coporaque celebrate the water when it arrives in the cleaned canals and ponds; people drink the water, pour chicha (maize beer) into it, and dance around the canals and inside the pond while playing festive music. Different variations of these festivals of cleaning the irrigation canals take place in all the communities of Colca Valley.

In these world-making practices, water emerges as a sentient and responsive entity and 'a living being' (Valderrama and Escalante 1988: 206). Farmers in Chivay usually call water by its common name Yakumama, which means water-mother, and they also use the name Mama Choqueshisha 'out of respect' (de respeto). Water is known as a female life source that connects humans, plants, animals, and spirits. Water-beings such as lakes and springs (qochas and pukyos), as well as the earth-mother (pachamama), mountain-lords (apus), and other placebeings in the Andean landscape that are often called earth-beings (tirakuna) (Allen 2002; de la Cadena 2015a) are not inherently benevolent or malevolent, but they are very demanding and can be quite capricious. They demand proper respect and gifts (pagos) in return for water, plants, fertility, and well-being (see also Ødegaard, this volume). These pagos usually consist of llama foetus, sugar, fat, food, alcohol, coca leaves, flowers, miniatures and other items. Offering pagos —also called iranta ${ }^{3}$ in Colca - to the earth-mother, mountains, and water springs is an intrinsic part of agricultural and irrigation practice in Colca Valley. When the environment, the weather, and the water supply change, the need for making pagos becomes evermore pressing, in order to secure the continued provision of water from the mountains.

During the past 20 years, it has become increasingly difficult to maintain a livelihood as a small-scale farmer in Colca because of tough market competition as well as harsh weather conditions that are increasingly explained by climate change. The changing climate translates into unstable seasons and extreme temperatures, in addition to water-related problems: decreasing water supply in the springs, dry pastures, and irregular rain. The changing weather and insecure water supply increase the importance of pagos/irantas to mountains and springs. In August 2011, I was invited to accompany a group of men from one of Chivay's three water users' commissions-who were going up to the mountains to make irantas to the high springs, located above 4000 metres of altitude. By each spring, the paqu (ritual expert) prepared the ingredients to an iranta, and we all participated by rolling balls of fat from llama (lama glama) called untu and making bouquets of coca leaves (erythroxylum coca) called k'intus, into 
which we blew our samay (breath, life-essence, vital force) while invoking the names of various beings: the place, the spring, the Lord Santiago who controls the lightening (so that he would not send a lot of lightening, but only rain), and finally the machulas (ancestors). Before burning the iranta, the paqu summoned the water (llamar al agua). He used seawater that had been brought in a bottle all the way from the Pacific Ocean, which he placed inside the spring. The paqu told me that the seawater 'will call for more water'. After burning the iranta, the paqu placed tiny ceramic goblets with chicha, sweet wine, and holy water in a box in the earth beside the spring. He explained: 'It is for here, for the spring, to drink. This will be preserved here and it is for the whole year. It is ... how should I put it ...-it is [her] pago. Like we sometimes toast [drink], they are also thirsty.' In local practices and narratives, springs, mountains, and other earthbeings have names and personal characteristics, and they can feel thirst, hunger, and respond to human action. ${ }^{4}$ Hence, through these ritual actions, water and water-beings are enacted as living nonhuman persons. To acknowledge the presence of these beings through what is locally talked about as 'respect' is part of living and making life in Colca today (Fig. 6.1).

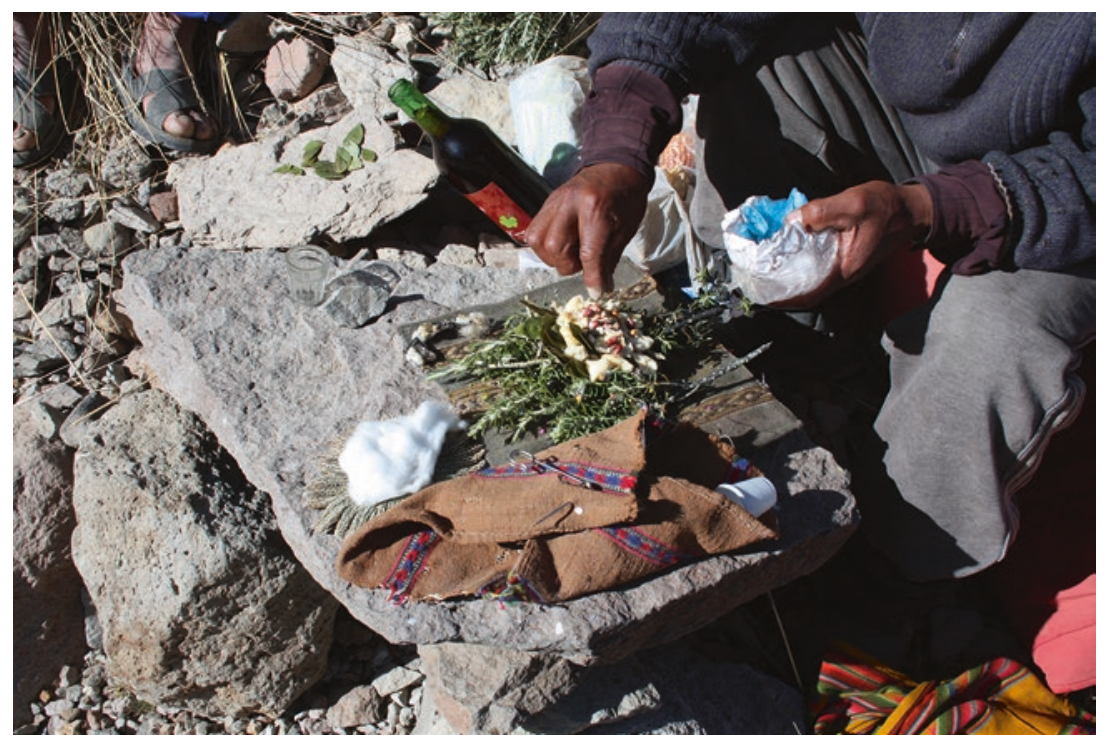

Fig. 6.1 A pago is prepared nearby a spring, with herbs, coca leaves, llama fat, and a dried star fish 


\section{Measuring Water}

With Canal Majes, the farmers living at the 'left riverbank' (la margen izquierda) in Colca Valley got a new source of water, but they did not achieve access without a fight. When the Canal Majes was completed in 1982, the farmers in Colca suffered from an extreme drought while they watched the water being channelled across their fields. Their petitions to the government, where they solicited access to this water, were ignored. Only after a group of 11 men from the village of Cabanaconde took action and blew a hole in the canal with dynamite, did the communities along the canal get access to the water to irrigate their lands. These men are still honoured as the 'eleven heroes' in Colca Valley (Gelles 2000). Today, the main marker of difference between the left and right side of the river valley relates to water access and agricultural production. While the farmers living at the right bank of Colca River (la margen derecha) continue to struggle with water scarcity, some farmer communities at the left riverbank have expanded their areas of cultivation with the allocated water from the Majes Canal. However, the water is not free of charge. Today there are 26 valves in the canal from which farmers in the villages Canocota, Chivay, Yanque, Achoma, Maca, Pinchollo, Cabanaconde, and Huambo are allocated regulated amounts of water. The water going into the Majes Canal in Tuti is regulated by AUTODEMA. The amounts are decided in monthly meetings where AUTODEMA, the state water administration, and the affected water users' organisations negotiate the distribution of water according to the supply in the Condoroma Dam and the farmers' demands in Majes and in Colca Valley. The valves are adjusted to a specific flow rate measured in litres per second, and there is a monthly valve regulation (regulación de válvulas) where the AUTODEMA engineers inspect the valves in the Majes Canal to ensure that the farmers do not use more water than they are allowed.

Since the 1990s, farmers have been obligated to pay a tariff for the irrigation water to the Water Users' Board (Junta de Usuarios), which is a private nonprofit association that is responsible for the maintenance and operation of the small-scale hydraulic infrastructure. The tariff is calculated according to land size and source: whether it is regulated water from the Majes Canal, unregulated water from natural springs and streams, or mixed water from both sources. The tariffs are not payments for the water per se, since water is public property by law, but for the use of infrastructure. Therefore, the water coming from the Majes Canal is the most expensive (between 26 and 40 soles a year per hectare), while unregulated water is cheap in comparison (between 12 and 15 soles). The Junta pays 
AUTODEMA, which is responsible for the maintenance of the Majes Canal, for the regulated water. All farmers in Majes pay the most expensive tariff for regulated water, while a farmer in Colca might pay both categories for the irrigation of different fields. Since 2006, farmers also have to pay an annual fee for a water licence, which is a formalised and permanent water use right for an amount of water measured in litres per second from a specific source. Registration and control require a simplification of nature to make it more susceptible to measurement, calculation, and manipulation, and this bureaucratic logic of legibility is practically synonymous with, or a requisite of, a commercial logic (Scott 1998). This means that the complexity of water-beings, water practices, and relationships is reduced into a uniform 'resource' that can be exploited for economic gain.

The payments came as a result of the liberalisation of markets that took off in the 1990s, when the Fujimori regime implemented massive privatisation and economic deregulation. The neoliberal restructuring and reduction of the state entailed a reversal of the agrarian reform-the cancellation of subsidies to farmers, and the removal of protectionist laws, allowing unlimited private property (Mayer 2009). The neoliberal Fujimori government failed at privatising water, but during the 1990s the staff of the water administration was reduced, and state functions in operation and maintenance of the irrigation infrastructure were handed over to the user organisations (Oré and Rap 2009). Hence, the water user commissions and the Junta in Colca were given more responsibilities and started charging the farmers a water tariff. In 2009, the García government passed the Law on Water Resources (Ley de Recursos Hidricos), which emphasises the economic value of water and the need for efficiency and modernity in water management (ANA 2010). The law gives ample space for private companies to intervene and invest in water management (del Castillo 2011).

The concession to construct and administer the second phase of MIPcalled Majes-Siguas II-has been awarded to a Spanish-Peruvian private consortium called Angostura-Siguas. Since the consortium will administer the canal for 20 years, the farmers in Majes and Colca fear that they will increase the water tariff to recover their investments. 'We call this privatisation', farmers repeatedly said. No matter how strongly the government argues that the water will still be public property, the farmers fear that the operator that administers the infrastructure will control the water flow. Additionally, they anticipate that big corporations, which are able to pay more for the water, will buy most of the land in Siguas. While the land in the first phase of Majes was sold in units of 5 hectares to subsidised prices, the land in Siguas will be sold in units of 200, 500 and 1000 hectares in 
order to attract big capital and ensure that large-scale export-oriented agribusiness will create economic growth. The annual goal is to generate USD 360 million from exports, which will substantially increase the agricultural GDP (Huanca 2014).

The Majes-Siguas II is highly promoted as a project for the future: for modernisation, progress, and development. In his speech for the inauguration of Majes-Siguas II in the pampa of Siguas on 6 February 2014, President Ollanta Humala promised a modern export-oriented agriculture where large-scale agribusiness corporations would create employment for 200,000 people and spur economic growth for the whole region (Campano 2014). The water for the expansion of the irrigated areas in Majes-Siguas II-38,500 hectares in the pampa of Siguas (adjacent to Majes)—will come from the planned Angostura Dam. Since 2009, farmers in the highland province of Espinar, in Cusco region, have protested against the Angostura Dam contending that it will leave them with less water. Espinar receives water from the headwaters of the Apurímac River Basin, which are the same sources that will feed Angostura. In 2011, the constitutional court stopped the project and ordered a new environmental impact assessment and water balance report. After the new report in 2013 had concluded that there is enough water, based on quantitative measurements of water resources, the court allowed the USD 550 million project to proceed as planned. The construction of the dam was supposed to start in April 2016, but the consortium and the regional government are still negotiating compensation and the value of land owned by farmers in Pusa Pusa. On the negotiating table are not only money but also the possibility of receiving land in Majes and also training in how to make a livelihood in a new environment.

While Majes is growing due to a booming economy, entrepreneurial activity, and population growth, the provincial capital Chivay and the other villages upriver in the Majes-Colca watershed experience a declining agriculture, decreasing water supplies, and out-migration of young people. The pastoral farmers in the headwaters are the first to experience the consequences of climate change and the last to get access to the benefits from infrastructural megaprojects of 'development'. In 2012, there were heated discussions about why Chivay should continue to be the capital of the Caylloma province, and the population of Majes wanted to separate from Caylloma to become a province apart. A couple of days after this had been publicly stated, the Majes Canal broke because of an earthquake in Colca Valley. When the water did not arrive in Majes, it caused a sense of crisis and made explicit the vulnerability of the place. Miguel, who worked for the Water Users' Board, suggested: 'It seems like the nature got annoyed. Like 
a sign, a message: that Majes depends on the highlands.' In modern discourse, such explanations are not possible; they are ridiculed, ignored, or at best patronised or 'tolerated' as culturally peculiar or silly jokes. Miguel was very much aware that from a scientific perspective, there is no nature with sentience and intentional agency, and he showed this in our conversation through moderating his statement by saying 'it seems like'. Miguel was born and raised in Chivay and had studied engineering at the University of Arequipa. As an engineer working with water management, he participates in the world of science, but he also participates in practices that make other worlds emerge: for example, he is cautious when approaching particular springs because they have life and powers. This shows the complexity of contemporary life in the Andes, where 'indigenous' and 'modern' worlds are not separate units but emerging realities and always overlapping (see also Stensrud 2016). However, despite his cautious qualification, he was not joking. On the contrary, he was deeply concerned about the importance of seeing and managing the whole watershed, including the headwater environment, the river, and the infrastructure. In Miguel's opinion, AUTODEMA has done what they wanted in the high parts of Caylloma without asking permission from local water authorities in order to lead water to Majes. According to the extractivist logic that sees water only as economic resource, the government prioritises the irrigation project in Majes because this is where the water's value is being exploited most efficiently and profitably. However, water cannot be treated as disconnected from the watershed and all its relationships along the river and canal. Water has always been highly valued in Colca, yet after the construction of the Majes Canal, the value of water has gained new economic and political meanings.

\section{Claiming Water}

The district of Callalli, where the Condoroma Dam is located, has not increased its supply of water as a result of MIP and does not receive any compensation for the water that is channelled down to Majes. The 2500 inhabitants in Callalli (called callallinos), just as people in the rest of the Colca-Majes headwaters above 4000 metres of altitude, are among the poorest in the region as they struggle to make a living on alpaca pastoralism, selling the wool and meat to wholesalers. Their harsh mountain environment is the most impacted by climate change: according to local authorities and farmers, glaciers have disappeared, springs have dried out, pastures are dry, the rain is more irregular, and when it finally comes, it 
falls so hard that it erodes the soil (Stensrud 2015). The incidents of strong frost periods and heavy snowfall are more common than before and harder to anticipate, and the local authorities have declared states of emergency in the high parts of Caylloma province almost every year since 2011.

The callallinos have been inspired by the protesters in Espinar because although they did not stop Majes-Siguas II, they were conceded compensation in the form of financial support to local infrastructure and other projects. In 2012, a group of 300 families from Callalli organised a collective claim to get the legal property rights to 400 hectares of arid land in Majes as well as infrastructure and water to irrigate and produce on this land. They claim that callallinos have the right to land and water in Majes because they belong to the headwater territory where the water comes from-the water which enables the export agriculture and economic growth in Majes. Hence, the water-and, by extension, the fertility of the land-also 'belong' to the headwaters in Callalli where it originates. Economy and production in the Andes have traditionally been organised vertically, which means that several ecological zones at different altitudes belong to the same community (Fonseca Martel 1972; Murra 2002).

In 2013 and 2014, while they were waiting for a response to the formal request, the callallinos appropriated the land by planting rows of trees along its borders. They visited the place regularly to water the plants and in this way cared for and nurtured the land. The claim for compensation for water echoes the environmental justice movement, in Latin America, also called 'ecologism of the poor', which addresses conflicts about unequal access to nature's services and resources and connects economic and ecological distribution to political power (Martínez Alier 1992). The callallinos take seriously the law on water resources, which gives priority to water's economic value and use this to justify their claim. However, there is another dimension to the claim that goes beyond political ecology; it emerges from world-making practices and life projects that open up for disagreements on the definition of nature and the world itself. When these ontological disagreements are brought into the public eye through such claims, it allows for pluriversal politics to unfold (Blaser 2009; de la Cadena 2010).

Victor, the initiator and leader of the group of claimants from Callalli, told me that if they did not get their land claim through, they would make a water war because 'we are the owners of the water! ... [we are the] owners of the earth, owners as cayllominos which is who we are because these lands belong to Caylloma'. Their claim of water ownership is based on the notion that water is conditionally given to them by the mountains, 
called apus (lords), who are powerful beings that guard the territories that they overlook (Gose 1994; Gelles 2000; Allen 2002). The gift of water is not permanent and cannot be taken for granted: the relationships of reciprocity and guardianship have to be reaffirmed each year through pagos and other ritual work. The mountain-lords can be vengeful and dangerous when they are disrespected or have not received offerings. Hence, living in this place implies taking part in intricate and affective relationships between humans and mountains, earth and water. Relationships to land and water have to be nurtured in order to ensure water supply and fertility of land and animals. Through these actions, humans are endowed with the right to use the water emanating from the land. This is translated as 'ownership', which in this case is processual and dynamic and based on care, nurture, and reciprocity, similarly to how it is practised in Amazonia (Brightman et al. 2016; see also Brightman, this volume). Since water comes from the mountain-lords who are its keepers, it also belongs to the territories and the people of which the apus are guardians.

Although this way of explaining belonging and ownership is very different from how property is established according to the state and the market, and although many are critical to neoliberalism and extractivism, the claim is not in opposition to the government. These callallinos are not aiming to stop the neoliberal and extractivist policies. Rather, they wish to be recognised as being part of the watershed and as having rights to water and land. They want to have a part of the benefits from MIP but according to their own terms. Víctor said: 'We have not come to beg for charity from anyone; on the contrary we come to contribute, we want to invest here.' What they are asking for is legitimate access to possibilities to invest, work, and produce. The deputy mayor of Callalli told me that the rearing of alpacas in Callalli and the cultivation of fodder in Majes are complementary activities; when there is scarcity of water and grass in the highlands, they can send fodder from Majes. In this way, the project is also about practising the vertical way of organising production across several ecological niches of different altitudes as it has been done in the Andes for centuries (Fonseca Martel 1972; Murra 2002).

When farmers and herders from the headwaters protest against the uneven distribution of resources, they are also demanding to be heard according to their own notions of ownership, belonging, and investment, which are embedded in particular ontological relationships. In the highlands, many farmers participate in giving offerings to the mountains as suppliers of water. In other words, people invest time and work in making 
territory where land, water, humans, animals, mountains, and infrastructure are connected in a relational web. From this territorial web emerges a form of ownership that exceeds the dichotomies of private versus public, individual versus collective, as well as the possessing subject versus the possessed object (cf. Brightman et al. 2016). Since the formal claim is clearly based on the political economic notion of the economic value of water resources and of compensating water for land, the callallinos have a chance to be heard. The outcome was still uncertain when this text was written, yet the municipality of Callalli have made new demands for land in the second phase, Majes-Siguas II (El Pueblo 2017). However, the legitimation for the claim in ontological relations between mountains, water, territories, and people is unheard of in public arenas. Although it is implied in the land claim, what is not seen-or not shown-in the formal paperwork is that water is a living being and a vital life-giving force that comes out of the sentient and powerful mountains. The practices that enact water as a sentient being are not yet part of a strategy to oppose or influence the government, although they are part of life- and world-making projects to sustain life, livelihood, and the relational web of the world.

\section{Conclusion}

Environmental conflicts in Peru often entail encounters between different kinds of knowledges and practices, as in the struggles against the Yanacocha Mine in the northern Peruvian highlands and against the mining concession in Mount Ausangate in Cusco (de la Cadena 2010; Li 2015). Hence, mountains can be included as earth-beings with agency in struggles against extractivist projects, which transforms these struggles into pluriversal politics (de la Cadena 2010). The state tends to see indigenous and/or local life-making and world-making projects as obstructions against development that should be overcome by education, economic persuasion, or force. This hegemonic view was most explicitly articulated by former President Alan García, who, in 2007, made social protests and strikes illegal. García accused the opponents of private investments for obstructing progress due to old ideologies, laziness, and inertia and because of the 'demagogy and deception that say that these lands cannot be touched because they are holy objects' (García Pérez 2007). Hence, earth-beings are only paid attention to as remnants of ancient beliefs and 'holy objects' that are allegedly used to obstruct progress. However, as shown in this chapter, earth-beings are not (only) employed as part of an indigenous 
strategy to stop extractivism, but they are part of relationships that are being continuously nurtured as part of ongoing life projects. In public discourse, the everyday relationships and encounters with existing earthand water-beings are silenced and made invisible; they are the 'anthroponot-seen' (de la Cadena 2015b). Therefore, the encounters with chinchilikos and the celebrations of the water-mother yakumama are not part of the official story of MIP. The Peruvian government's hegemonic project is to achieve development, progress, and economic growth through modernisation and extractivism. This involves making water modern, that is, to transform the multiplicity of water into a standardised and neutral substance that can be extracted as an economic resource and transformed into products and profits. The modernising project also entails creating a coherent and legible land- and waterscape that can be measured, registered, and controlled by the state. Hence, modernised water as economic resource is colonialised water. This extractivist and modernising/colonising project is not compatible with sustaining world-making and lifemaking projects, in which water is multiple and ontologically different. Water as a living being and as a gift from the mountains cannot be easily 'scaled up' and transformed into a homogenous, legible, and commercialised resource. Seeing water not as universal but as constituted in practice, allows us to perceive water and the world itself as emerging, as always becoming in different versions, and as multiple realities.

Acknowledgements The research leading to this chapter has received funding from the European Research Council (ERC Grant Agreement number 295843) and the Research Council of Norway (NFR project number 222783). The author would like to thank Juan Javier Rivera Andía and Cecilie Vindal Ødegaard for their insightful and critical comments on this chapter.

\section{Notes}

1. In this chapter, Majes is the name of the arid pampa between the river valley of Majes and the river valley of Siguas, and it is also the name of the irrigation project in this pampa and the name of the irrigation canal leading water from the Colca River. Majes is further the name of the new district that was created in 1999 as part of Caylloma Province in Arequipa Region.

2. The chinchilikos seem to be very similar to the muki, which has been described in ethnographies from the central Andes, see, for example, SalazarSoler (1987). 
3. The anthropologists Valderrama and Escalante (1988: 109) translated iranta as 'food for the gods'. According to the Quechua-Spanish dictionary of Academia Mayor (2005), the verb irantay means to fill a special container with grease for the pago to Pachamama. According to Adelaar (2004: 278), a translation from Aymara would be 'to introduce small objects'.

4. There are similar ritual practices related to water in various places in the Peruvian highlands. See, for example, Borea Labarthe (2004).

\section{REFERENCES}

Academia Mayor de la Lengua Quechua. 2005. Diccionario Quechua-EspañolQuechua. 2nd ed. Cusco: Gobierno Regional.

Adelaar, Willem F.H. 2004. The Languages of the Andes. Cambridge: Cambridge University Press.

Allen, Catherine J. 1997. When Pebbles Move Mountains. Iconicity and Symbolism in Quechua Ritual. In Creating Context in Andean Cultures, ed. R. HowardMalverde. New York: Oxford University Press.

- 2002. The Hold Life Has. Coca and Cultural Identity in an Andean Community. 2nd ed. Washington, DC: Smithsonian Institution Press.

ANA (Autoridad Nacional del Agua). 2010. Ley de recursos hidricos y su reglamento. Ley No 29338. Lima: Ministerio de Agricultura.

Blaser, Mario. 2004. Life Projects: Indigenous People's Agency and Development. In In the Way of Development. Indigenous Peoples, Life Projects and Globalization, ed. Mario Blaser, Harvey A. Feit, and Glenn McRae. London: Zed Books.

- 2009. The Threat of the Yrmo: The Political Ontology of a Sustainable Hunting Program. American Anthropologist 111 (1): 10-20.

Borea Labarthe, Giuliana. 2004. Trás los pasos del parian en el evento y en el tiempo. Imagenes y representaciones en la sierra de Lima. Anthropológica 22 (22): 151-178.

Brightman, Marc, Carlos Fausto, and Vanessa Grotti. 2016. Introduction. Altering Ownership in Amazonia. In Ownership and Nurture. Studies in Native Amazonian Property Relations, ed. Marc Brightman, Carlos Fausto, and Vanessa Grotti. New York: Berghahn Books.

Campano, Magaly. 2014. Majes Siguas II es un proyecto importante para el desarrollo del país. Diario Correo, February 6. https://diariocorreo.pe/ciudad/ majes-siguas-ii-es-un-proyecto-importante-p-52711/. Accessed 19 Dec 2017.

Cereceda, Verónica. 2006. Mito e imagines andinas del infierno. In Mitologías Amerindias, ed. Alejandro Ortiz Rescaniere. Madrid: Editorial Trotta.

CIP (Colegio de Ingenieros del Perú). 2013. Ambicioso y esperado proyecto multipropósito Majes-Siguas II. Ingeniería Nacional. Revista Oficial del Colegio de Ingenieros del Perú, Consejo Nacional 3 (12): 40-42.

Collier, David. 1978. Barriadas y élites: de Odría a Velasco. Lima: IEP. 
de la Cadena, Marisol. 2010. Indigenous Cosmopolitics in the Andes: Conceptual Reflections Beyond 'Politics'. Cultural Anthropology 25 (2): 334-370.

- 2015a. Earth-Beings. Ecologies of Practice Across Andean Worlds. Durham: Duke University Press.

- 2015b. Uncommoning Nature. http://supercommunity.e-flux.com/ authors/marisol-de-la-cadena/. Accessed 16 Sept 2015.

del Castillo, Laureano. 1994. Lo bueno, lo malo y lo feo de la legislación de aguas. Debate Agrario 18: 1-20.

- 2011. Ley de Recursos Hídricos: Necesaria pero no suficiente. Debate Agrario 45: 91-118.

El Pueblo. 2017. Callalli también pide terrenos en proyecto Majes-Siguas II. El Pueblo, March 2. http://elpueblo.com.pe/noticia/locales/callalli-tambienpide-terrenos-en-proyecto-majes-siguas-ii. Accessed 15 Oct 2017.

Escobar, Arturo. 2007. Worlds and Knowledges Otherwise. Cultural Studies 21 (2-3): 179-210.

Fernández Juárez, Gerardo. 2013. El ‘Tío’ está sordo: Los mineros bolivianos y el Patrimonio Cultural Inmaterial. Revista de Antropología Iberoamericana 8 (3): 303-322.

Fonseca Martel, Cesar. 1972. La economía 'vertical' y la economía de mercado en las comunidades alteñas del Perú. In Visita de la Provincia de León de Huánuco en 1562, ed. John V. Murra and Ortiz de Zúñiga, vol. 2. Huánuco: Universidad Nacional Hermilio Valdizán de Huánuco.

García Pérez, Alan. 2007. El síndrome del perro del hortelano. El Comercio, October 28. http://elcomercio.pe/edicionimpresa/html/2007-10 28/el_ sindrome_del_perro_del_hort.html

Gelles, Paul H. 2000. Water and Power in Highland Peru: The Cultural Politics of Irrigation and Development. New Brunswick: Rutgers University Press.

Gose, Peter. 1994. Deathly Waters and Hungry Mountains: Agrarian Ritual and Class Formation in an Andean Town. Toronto: University of Toronto Press.

Harvey, Penny, and Hannah Knox. 2015. Roads. An Anthropology of Infrastructure and Expertise. Ithaca: Cornell University Press.

Huanca, Elizabeth. 2014. Así funcionará la segunda etapa del proyecto Majes Siguas. La República, February 10. http://larepublica.pe/archivo/771336-asifuncionara-la-segunda-etapa-del-proyecto-majes-siguas. Accessed 30 Nov 2017.

Li, Fabiana. 2015. Unearthing Conflict: Corporate Mining, Activism and Expertise in Peru. Durham: Duke University Press.

Los Andes. 2011. Ignorancia de García Pérez califica de absurdas creencias andinas (Video). Los Andes, June 17. http://www.losandes.com.pe/ Nacional/20110617/51373.html. Accessed 5 May 2017.

Maldonado-Torres, Nelson. 2007. Sobre la colonialidad del ser: contribuciones al desarrollo de un concepto. In El giro decolonial. Reflexiones para una diversi- 
dad epistémica más allá del capitalismo global, ed. Santiago Castro-Gómez and Ramón Grosfoguel. Bogotá: Iesco-Pensar-Siglo del Hombre Editores.

Martínez Alier, Joan. 1992. De la economía ecológica al ecologismo popular. Barcelona: Icaria.

Mayer, Enrique. 2009. Ugly Stories of the Peruvian Agrarian Reform. Durham: Duke University Press.

Mignolo, Walter D. 2000. Local Histories/Global Designs: Coloniality, Subaltern Knowledges, and Border Thinking. Princeton: Princeton University Press.

Mol, Annemarie. 2002. The Body Multiple: Ontology in Medical Practice. Durham: Duke University Press.

Murra, John V. 2002. El Mundo Andino: población, medio ambiente y economía. Lima: IEP/Pontificia Universidad Católica del Perú.

Nash, June. 1979. We Eat the Mines and the Mines Eat Us: Dependency and Exploitation in Bolivian Tin Mines. New York: Columbia University Press.

Oré, María Teresa, and Edwin Rap. 2009. Políticas neoliberales de agua en el Perú. Antecedentes y entretelones de la ley de recursos hídricos. Debates en Sociología 34: 32-66.

Salazar-Soler, Carmen. 1987. El Tayta Muki y la Ukupacha. Prácticas y creencias religiosas de los mineros de Julcani, Huancavelica, Perú. Journal de la Société des américanistes 73 : 193-217.

Scott, James C. 1998. Seeing Like a State: How Certain Schemes to Improve the Human Condition Have Failed. New Haven: Yale University Press.

Stensrud, Astrid B. 2015. Raining in the Andes: Disrupted Seasonal and Hydrological Cycles. In Waterworlds: Anthropology in Fluid Environments, ed. Kirsten Hastrup and Frida Hastrup. New York: Berghahn Books.

- 2016. "It Seems Like a Lie": The Everyday Politics of World-Making in Contemporary Peru. In Critical Anthropological Engagements in Human Alterity and Difference, ed. Synnøve Bendixen and Bjørn E. Bertelsen. London: Palgrave Macmillan.

Taussig, Michael. 1980. The Devil and Commodity Fetishism in South America. Chapel Hill: University of North Carolina Press.

Valderrama, Ricardo, and Carmen Escalante. 1988. Del Tata Mallku a la Mama Pacha: Riego, sociedad y ritos en los andes peruanos. Lima: DESCO.

Zamalloa, Edgar Bravo. 2013. Reseña Histórica del Distrito de Majes. Lima: Corporación Grafical. 
Open Access This chapter is licensed under the terms of the Creative Commons Attribution 4.0 International License (http://creativecommons.org/licenses/ by $/ 4.0 /)$, which permits use, sharing, adaptation, distribution and reproduction in any medium or format, as long as you give appropriate credit to the original author(s) and the source, provide a link to the Creative Commons license and indicate if changes were made.

The images or other third party material in this chapter are included in the chapter's Creative Commons license, unless indicated otherwise in a credit line to the material. If material is not included in the chapter's Creative Commons license and your intended use is not permitted by statutory regulation or exceeds the permitted use, you will need to obtain permission directly from the copyright holder.

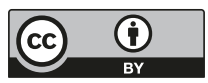

